\title{
The Effect of Dietary Probiotics on Growth, Survival and Stress Resistance of Rainbow Trout (Onchorynchus Mykiss Walbaum)
}

\author{
Panagiotis A. Pantazis ${ }^{1 *}$, Georgia Kouneli ${ }^{2}$, Markos Kolygas ${ }^{2}$, John Ch. Karamaligas ${ }^{1}$, Foteini \\ Athanassopoulou ${ }^{2}$ \\ ${ }^{I}$ Department of Animal Husbandry and Nutrition, Faculty of Veterinary Medicine, University of Thessaly, \\ Greece \\ ${ }^{2}$ Department of Ichthyology, Aquatic Fauna \& Fish Diseases, Faculty of Veterinary Medicine, University of \\ Thessaly, Greece
}

*Corresponding Author: Panagiotis A. Pantazis, Department of Animal Husbandry and Nutrition, Faculty of Veterinary Medicine, University of Thessaly, Greece

\begin{abstract}
Hundred fifty rainbow trout of an average weight of $108 \pm 6.79 \mathrm{~g}$ have been kept for sixty days in $700 \mathrm{~L}$ tanks and various temperature regimes. They were fed two different diets, the one with probiotics containing Pediococcus acidilactici (CNCM MA 18/5M) and the other one without probiotics. All groups gained weight, however observed growth rate and weight gain have been considerably lower when fish over passed the $200 \mathrm{~g}$ size class. No significant differences were shown between the two groups kept in lower temperatures in terms of growth rate, weight gain, feed conversion and protein utilization. Trout kept in natural temperature conditions fed either with probiotics or without probiotics, did not differ dramatically in between them in terms of growth rate and weight gain. However the ones fed with probiotics have experienced better feed conversion and protein utilization. Fish which have received dietary probiotics had lower serum cortisol levels and better $\mathrm{Na}+$ and $\mathrm{Cl}$ - serum equilibrium than those which have not received probiotics, indicating that probiotics increased the stress resistance of experimental fish, even after the oxygen depletion test. Results of this study confirm that $P$. acidilactici in rainbow trout enhances its welfare and disease resistance and therefore should be used even at high size classes (100-200g).
\end{abstract}

Keywords: Rainbow trout, probiotics, growth, aquaculture, nutrition, stress, serum cortisol.

\section{INTRODUCTION}

The American rainbow trout has been imported in Europe since the late 50's and remains a worldwide aquaculture commodity due to its ability to adapt to various culture conditions, to accept artificial diet at a very early stage, to its satisfying growth rates and its broad acceptability by consumers worldwide.

The annual rainbow trout production in Greece is app. 3,000.00 tons and as the total Hellenic human population amounts to 11 million the average theoretical consumption of rainbow trout in Greece is app. $0.3 \mathrm{~kg} / \mathrm{capita} /$ year while the total average fish consumption in Greece is app. $23.3 \mathrm{~kg} / \mathrm{capita} /$ year. Consumer's preference in Greece balances over marine species as the annual sea bass and sea bream aquaculture production amounts to app. 110,000.00 tons/year [1]. However rainbow trout always remains an export commodity for Central and Eastern Europe, particularly for the ex-soviet member states where the per capita fish consumption remains relatively low $(<20 \mathrm{~kg} /$ capita/year) [2].

Probiotics are nutritional supplements comprised of live microbial cultures aiming at stabilizing the intestinal flora by the use of beneficial microorganisms at the expense of pathogenic ones. Some of these microorganisms secrete anti-bacterial substances as well, boosting the immune response and promoting growth [3]. In order that a microorganism can be used as a probiotic, it needs to meet the following criteria: to be able to survive at $\mathrm{pH}$ intestinal levels, to be resistant to most antibiotics used in aquaculture and to be able to have an antagonistic effect to most pathogenic microorganisms (mainly bacteria) found in the intestinal tract of fish. Most probiotics are oxygalactic bacteria (LAB), however Aeromonas spp has also been shown to have a beneficial effect against Saprolegniasis in Anguilla australis. The beneficial effect of probiotics in aquaculture has recently been reviewed: they 
are primarily able to minimize the use of antibiotics and increase the stress resistance and immune response of cultured species to various adverse culture conditions and pathogens. It has also been shown that in some cases they may enhance growth and improve feed conversion [4].

A number of previous research studies have shown the benefits of probiotics for rainbow trout. Lactobacillus rhamnosus JCM136 has been shown to have a beneficial effect on the immune response of rainbow trout [5, 6]. Robertson et al. [7] have shown the beneficial effect of Carnebacterium spp. in rainbow trout and Atlantic salmon. Irianto \& Austin [8] and Burbank et al. [9] have shown the increased resistance of rainbow trout towards furunculosis after the administration of dietary probiotics. Aeromonas infection can also be controlled by Bacillus subtilis AB1 in rainbow trout [4]. The oral administration of the bacteria Clostridium butyricum in rainbow trout has reinforced the strength resistance of the fish to vibriosis [10].

Pediococcus acidilactici is to date, the only authorized dietary fish probiotic in the European Union [11]. This experiment aimed at investigating the effect of Pediococcus acidilactici (CNCM MA $18 / 5 \mathrm{M}$ ) contained in a commercially prepared fish feed, on the growth, survival and stress resistance of the rainbow trout Onchorynchus mykiss, kept in water-recirculation systems.

\section{MATERIALS AND MeTHODS}

\subsection{Experimental Set Up and Husbandry}

The experiment took place at the installations of the Department of Ichthyology, Aquatic Fauna and Fish Diseases of the Faculty of Veterinary Medicine, University of Thessaly, Greece. The following protocols have been applied:

1. Protocol PNT (feed With Probiotics at Natural Temperature conditions)

2. Protocol WPNT (feed Without Probiotics at Natural Temperature conditions)

3. Protocol P17 (feed with Probiotics at $16 \pm 1.0^{\circ} \mathrm{C}$ )

4. Protocol P19 (feed with Probiotics at $18 \pm 1.0^{\circ} \mathrm{C}$ )

Hundred fifty rainbow trout of an average weight of $108 \pm 6.79 \mathrm{~g}$ have been randomly allocated to twelve 700L tanks (three replicates per treatment), each tank having its own water recirculation and biofiltration system. The stocking density ranged from $1.5-2 \mathrm{~kg} / \mathrm{m}^{3}$. Six of the tanks were part of a purposely designed water cooling system, able to maintain water temperature at low levels, required for protocols P17 and P19, while the rest of tanks (PNT \& WPNT) were running at natural levels of water temperature $\left(25^{\circ} \pm 1.5^{\circ} \mathrm{C}\right)$.

\subsection{Sampling and Performance Indices}

The experiment lasted for sixty days. Three samplings have been performed, the first at the onset of the experiment and the rest of two at a month's interval following the first. During sampling, fish have been anaesthetized by tricaine $(0.125-0.2 \mathrm{ml} / \mathrm{L})$ and their wet weight and standard length (SL) have been recorded. A $1 \mathrm{ml}$ syringe has collected blood from the caudal vein, the blood has been centrifuged at 3,000rpm for 2 minutes (Centurion Scientific Ltd) and the supernatant serum has been kept at $2-3^{\circ} \mathrm{C}$ for further biochemical analyses. The following serum parameters have been estimated: glucose, total protein, cortisol, $\mathrm{K}^{+}, \mathrm{Na}, \mathrm{Cl}^{-}$

The oxygen depletion test has been effected at the end of the 2 nd experimental period and as previously described [12]: hypoxia was produced by stopping the water supply to the tanks and reducing simultaneously the rate of tank aeration. After the onset of stress, dissolved oxygen levels decreased from normal levels to $1.0 \mathrm{mg} / \mathrm{L}$ within an hour, and were maintained at this level $( \pm 0.1$ $\mathrm{mg} / \mathrm{L}$ ) until the end of the challenge ( $2 \mathrm{hrs}$ ), by adjusting the aeration.

The performance of the various treatments has been estimated by the following indices:

Feed conversion ratio (FCR)

$\mathrm{FCR}=[$ dry feed intake $(\mathrm{g}) /$ wet weight gain $(\mathrm{g})]$

Specific growth rate (SGR) 
The Effect of Dietary Probiotics on Growth, Survival and Stress Resistance of Rainbow Trout (Onchorynchus Mykiss Walbaum)

$\mathrm{SGR}=[(\ln \mathrm{FBW}-\ln \mathrm{IBW}) /(\mathrm{t} 1-\mathrm{t} 2)]^{*} 100$

FBW = final body weight, IBW= initial body weight, T1-T2 = Number of days of trial

Percentage Weight Gain $(\mathrm{PWG})=100 *[(\mathrm{FBW}-\mathrm{IBW}) / \mathrm{IBW}]$

Protein Efficiency Ratio (PER) (Osborne-Mendel, 1919; Steffens 1989).

$\mathrm{PER}=[(\mathrm{FBW}-\mathrm{IBW}) /$ Weight of Protein consumed $]$

Thermal Unit Growth Coefficient; (Cowey 1992).

TUGC $=\left[\mathrm{W}_{\mathrm{F}}^{0,333}-\mathrm{W}_{\mathrm{I}}^{0,333}\right] / \Sigma\left[\right.$ Temp $\mathrm{C}^{0} *$ Days $]$,

$\mathrm{W}_{\mathrm{F}}=$ final average weight, $\mathrm{W}_{\mathrm{I}}=$ initial average weight

Condition coefficient $(\mathrm{K})=100 *\left(\mathrm{BW} / \mathrm{TL}^{\mathrm{b}}\right)$ where $\mathrm{BW}=$ Body Weight in $\mathrm{mg}$ and $\mathrm{TL}=$ Total Length in $\mathrm{cm}$ and the coefficient $\mathrm{b}$ from the equation $\mathrm{W}=\mathrm{aL}^{\mathrm{b}}$

\subsection{Experimental Diets}

Diets were provided by a commercial fish feed manufacturer with the probiotic Pediococcus acidilactici already incorporated during the manufacturing process in the feed processing plant.

The biochemical profile of the diets ( $\%$ as fed) as declared by the manufacturer, has been:

Diet with Probiotics: Dry matter 91.5, Crude Protein 52, Crude Lipid 19, Crude Fiber 1.5, Ash 9, NFE 18.5

Diet without Probiotics: Dry matter 91.5, Crude Protein 52, Crude Lipid 18.5, Crude Fiber 1.5, Ash 9, NFE 19.

\subsection{Water Quality and Statistical Analysis}

Water quality has been recorded by a Hanna C200 / HI83000 spectrophotometer and a Handy Polaris Oxyguard oxygen meter. Statistical analysis of data was performed by ANOVA and the multiple range tests (Scheffe) have indicated the statistical differences by using SPSS MS WINDOWS Release 6.1. Software.

\section{RESULTS \& DISCUSSION}

Water quality has been recorded as follows: $\mathrm{N}^{-N_{3}}=0.037 \pm 0.06 \mathrm{mg} / \mathrm{Lt}, \mathrm{N}-\mathrm{NO}_{3}=33 \pm 15 \mathrm{mg} / \mathrm{Lt}, \mathrm{N}-$ $\mathrm{NO}_{2}=0.65 \pm 0.2 \mathrm{mg} / \mathrm{Lt}, \mathrm{O}_{2}=7.4 \pm 0.2 \mathrm{mg} / \mathrm{Lt}(90 \%$ sat DO for the PNT \& WPNT protocols $), \mathrm{O}_{2}=$ $8.52 \pm 0.37 \mathrm{mg} / \mathrm{Lt}$ (90\% sat DO for the $\mathrm{P} 17 \& \mathrm{P} 19$ protocols), $\mathrm{pH}=6.8 \pm 0.2$.

All performance indices are shown on Tables 1 to 8 , whereas serum biochemical parameters are shown in Tables 9 to 11 .

Table1. Average Weights ( $g$ ) of all experimental groups

\begin{tabular}{|l|l|l|l|l|}
\hline & PNT $*$ & WPNT $*$ & P17 $^{* *}$ & P19 $^{* * *}$ \\
\hline $1^{\text {st }}$ Sampling & $104.20 \pm 5.47^{\mathrm{a}, 1}$ & $105.62 \pm 5.28^{\mathrm{a}}$ & $96.1 \pm 12.3^{\mathrm{a}}$ & $106.59 \pm 10.48^{\mathrm{a}}$ \\
\hline $2^{\text {nd }}$ Sampling & $196.78 \pm 14.13^{\mathrm{a}}$ & $197.85 \pm 18.46^{\mathrm{a}}$ & $99.3 \pm 8.40^{\mathrm{b}}$ & $118.40 \pm 15.29^{\mathrm{c}}$ \\
\hline $3^{\text {rd }}$ Sampling & $220.46 \pm 12.24^{\mathrm{a}}$ & $230.77 \pm 23.2^{\mathrm{a}}$ & $142.56 \pm 14.27^{\mathrm{b}}$ & $148.06 \pm 17.65^{\mathrm{b}}$ \\
\hline
\end{tabular}

$* T=24 \circ \mathrm{oC} \pm 1.5 * * T=16.5 \circ \mathrm{o} \pm 1.0 * * * T=18.0 \circ \mathrm{o} \pm 1.0$

1. Similar superscripts in the same row are not significantly different

Table2. Average Standard Length (cm) of all experimental groups

\begin{tabular}{|l|l|l|l|l|}
\hline & PNT $*$ & WPNT $^{*}$ & P17 $* *$ & P19 $* * *$ \\
\hline $1^{\text {st }}$ Sampling & $19.46 \pm 0.40^{\text {a }, 1}$ & $21.19 \pm 0.17^{\mathrm{b}}$ & $18.81 \pm 0.85^{\mathrm{a}}$ & $19.71 \pm 0.64^{\mathrm{a}}$ \\
\hline $2^{\text {nd }}$ Sampling & $22.36 \pm 0.54^{\mathrm{a}}$ & $23.50 \pm 0.51^{\mathrm{b}}$ & $20.61 \pm 0.66^{\mathrm{c}}$ & $21.80 \pm 0.97^{\mathrm{d}}$ \\
\hline $3^{\text {rd }}$ Sampling & $24.01 \pm 0.39^{\mathrm{a}}$ & $27.40 \pm 0.63^{\mathrm{b}}$ & $22.63 \pm 0.67^{\mathrm{c}}$ & $23.04 \pm 0.80^{\mathrm{c}}$ \\
\hline
\end{tabular}

$* T=24 o C \pm 1.5 * * T=16.5 \circ C \pm 1.0 * * * T=18.0 \circ \mathrm{oC} \pm 1.0$

1. Similar superscripts in the same row are not significantly different

International Journal of Innovative Studies in Aquatic Biology and Fisheries (IJISABF) 
The Effect of Dietary Probiotics on Growth, Survival and Stress Resistance of Rainbow Trout (Onchorynchus Mykiss Walbaum)

Table3. Average Condition Coefficients $(K)$ of all experimental groups

\begin{tabular}{|l|l|l|l|l|}
\hline & PNT & WPNT & P17 & P19 \\
\hline $1^{\text {st }}$ Sampling & 2.55 & 3.04 & 2.27 & 1.27 \\
\hline $2^{\text {nd }}$ Sampling & 4.64 & 2.15 & 0.52 & 0.095 \\
\hline $3^{\text {rd }}$ Sampling & 0.43 & 0.23 & 0.22 & 0.42 \\
\hline
\end{tabular}

$* T=24 o C \pm 1.5 * * T=16.5 \circ C \pm 1.0 * * * T=18.0 \circ \mathrm{oC} \pm 1.0$

Table4. Specific Growth Rate (SGR \%) of all experimental groups

\begin{tabular}{|l|l|l|l|l|}
\hline & PNT $*$ & WPNT $*$ & P17 $* *$ & P19*** \\
\hline $1^{\text {st }}-2^{\text {nd }}$ Sampling & 0.96 & 0.96 & 0.65 & 0.58 \\
\hline $2^{\text {nd }}-3^{\text {rd }}$ Sampling & 0.17 & 0.23 & 1.17 & 1.39 \\
\hline
\end{tabular}

$* T=24 o C \pm 1.5 * * T=16.5 \circ C \pm 1.0 * * * T=18.0 \circ \mathrm{oC} \pm 1.0$

Table5. Percentage Weight Gain (\%) of all experimental groups

\begin{tabular}{|l|l|l|l|l|}
\hline & PNT $*$ & WPNT $*$ & P17** & P19*** \\
\hline $1^{\text {st }}-2^{\text {nd }}$ Sampling & 88.85 & 87.96 & 4.93 & 11.32 \\
\hline $2^{\text {nd }}-3^{\text {rd }}$ Sampling & 12.03 & 11.53 & 43.49 & 25.05 \\
\hline
\end{tabular}

* $T=24 o C \pm 1.5 * * T=16.5 o C \pm 1.0 * * * T=18.0 \circ C \pm 1.0$

Table6. Food Conversion Ratio (FCR) of all experimental groups

\begin{tabular}{|l|l|l|l|l|}
\hline & PNT $*$ & WPNT $*$ & P17** & P19*** \\
\hline $1^{\text {st }}-2^{\text {nd }}$ Sampling & 1.03 & 2.67 & 1.31 & 2.61 \\
\hline $2^{\text {nd }}-3^{\text {rd }}$ Sampling & 2.30 & 2.73 & 1.25 & 1.37 \\
\hline
\end{tabular}

$* T=24 o C \pm 1.5 * * T=16.5 \circ C \pm 1.0 * * * T=18.0 \circ C \pm 1.0$

Table7. Protein Efficiency Ratio (PER) of all experimental groups

\begin{tabular}{|l|l|l|l|l|}
\hline & PNT $^{*}$ & WPNT & P17** & P19*** \\
\hline $1^{\text {st }}-2^{\text {nd }}$ Sampling & 0.46 & 0.27 & 0.19 & 0.20 \\
\hline $2^{\text {nd }}-3^{\text {rd }}$ Sampling & 0.095 & 0.097 & 0.25 & 0.36 \\
\hline
\end{tabular}

$* T=24 o C \pm 1.5 * * T=16.5 \circ C \pm 1.0 * * * T=18.0 \circ \mathrm{o} \pm 1.0$

Table8. Thermal Unit Growth Coefficient (TUGC) of all experimental groups

\begin{tabular}{|l|l|l|l|l|}
\hline & PNT $^{*}$ & WPNT & P17** & P19** \\
\hline $1^{\text {st }}-2^{\text {nd }}$ Sampling & 0.068 & 0.061 & 0.015 & 0.047 \\
\hline $2^{\text {nd }}-3^{\text {rd }}$ Sampling & 0.015 & 0.034 & 0.065 & 0.045 \\
\hline
\end{tabular}

$* T=24 o C \pm 1.5 * * T=16.5 o C \pm 1.0 * * * T=18.0 \circ \mathrm{o} \pm 1.0$

Table9. Serum biochemical parameters $f$ groups kept under natural temperature

\begin{tabular}{|l|l|l|l|l|}
\hline & $\begin{array}{l}\text { PNT / 1st } \\
\text { sampling* }\end{array}$ & $\begin{array}{l}\text { WPNT / 1st } \\
\text { sampling }\end{array}$ & $\begin{array}{l}\text { PNT / 2nd } \\
\text { sampling** }\end{array}$ & $\begin{array}{l}\text { WPNT / 2nd } \\
\text { sampling }\end{array}$ \\
\hline Glucose mg/dL & 89.5 & 101.5 & 33 & 34 \\
\hline T.Protein g/dL & 2.57 & 3.05 & 3.33 & 3.81 \\
\hline Cortizole $\mu \mathrm{g} / \mathrm{dL}$ & 12.18 & 17.77 & 9.64 & 20.53 \\
\hline $\mathrm{K} \mathrm{mEq} / \mathrm{L}$ & 0.73 & 0.85 & 0.74 & 0.89 \\
\hline $\mathrm{Na} \mathrm{mEq/L}$ & 154.55 & 183.7 & 162.7 & 166.80 \\
\hline $\mathrm{Cl} \mathrm{mEq/L}$ & 130.55 & 158.6 & 139.10 & 140.20 \\
\hline
\end{tabular}

* At the end of the 1st rearing period

** At the end of the 2 nd rearing period

Table10. Serum biochemical parameters of groups kept under controlled temperature

\begin{tabular}{|l|l|l|l|l|}
\hline & P17/1st sampling* & P19/1st sampling & P17/ 2nd sampling** & P19/2nd sampling \\
\hline Glucose mg/dL & 40.0 & 44 & 84 & 83 \\
\hline T.Protein g/dL & 3.21 & 4.1 & 3.1 & 3.4 \\
\hline Cortizole $\mu \mathrm{g} / \mathrm{dL}$ & 7.23 & 9.05 & 7.04 & 8.17 \\
\hline $\mathrm{K} \mathrm{mEq} / \mathrm{L}$ & 1.57 & 1.57 & 1.03 & 1.09 \\
\hline $\mathrm{Na} \mathrm{mEq} / \mathrm{L}$ & 160.80 & 159.5 & 164.0 & 161.7 \\
\hline $\mathrm{Cl} \mathrm{mEq} / \mathrm{L}$ & 131.50 & 131.3 & 137.8 & 134.9 \\
\hline
\end{tabular}

* At the end of the 1st rearing period

** At the end of the 2 nd rearing period

International Journal of Innovative Studies in Aquatic Biology and Fisheries (IJISABF) 
The Effect of Dietary Probiotics on Growth, Survival and Stress Resistance of Rainbow Trout (Onchorynchus Mykiss Walbaum)

Table11. Serum biochemical parameters of all the groups after the oxygen depletion test

\begin{tabular}{|l|l|l|l|l|}
\hline & P17 & P19 & PNT & WPNT \\
\hline Glucose $\mathrm{mg} / \mathrm{dL}$ & 172.25 & 157 & 159.5 & 181.5 \\
\hline T.Protein g/dL & 2.6 & 2.85 & 2.67 & 3.25 \\
\hline Cortizole $\mu \mathrm{g} / \mathrm{dL}$ & 22.73 & 20.07 & 23.78 & 25.67 \\
\hline $\mathrm{K} \mathrm{mEq} / \mathrm{L}$ & 2.97 & 3.26 & 1.73 & 1.85 \\
\hline $\mathrm{Na} \mathrm{mEq} / \mathrm{L}$ & 158.6 & 157.7 & 155.6 & 184.5 \\
\hline $\mathrm{Cl} \mathrm{mEq} / \mathrm{L}$ & 131.6 & 132.97 & 132.6 & 159.5 \\
\hline
\end{tabular}

All groups gained weight (Table 1), however observed SGR and PWG have been considerably lower when fish over passed the $200 \mathrm{~g}$ size class. This has also affected negatively the observed food utilization (FCR) and food protein efficiency for the same size classes (Tables $6 \& 7$ ).

No significant differences were shown between the two groups kept in lower temperatures (P17, P19) in terms of growth rate, weight gain, feed conversion and protein utilization (Tables 4 to 7). The lower achieved final weights by groups kept in lower temperatures (P17, P19) are not a surprise since temperatures for the groups kept in natural conditions have been considerably higher (despite the psychrophilic nature of the species).

Trout kept in natural temperature conditions fed either with probiotics (PNT) or without probiotics (WPNT), did not differ dramatically in between them in terms of growth rate (SGR - Table 4) and weight gain (PWG - Table 5). However the ones fed with probiotics have experienced better feed conversion (FCR - Table 6) and protein utilization (PER - Table 7). This growth retardation but better feed utilization has previously been shown for tilapia and prawn after the administration of a probiotic containing Bacillus subtilis [13].

A similar experiment with juvenile rainbow trout (initial weight of $16.4 \pm 0.4 \mathrm{~g}$ ) but also using Pediococcus acidilactici as a probiotic had produced similar values for FCRs and Condition Coefficients but higher PER \& SGR values [14]. On another experiment with juvenile rainbow trout of an average initial weight of $9 \mathrm{~g}$ using again Pediococcus acidilactici as a probiotic, values for FCRs and Condition Coefficients have been similar to the ones observed in this experiment whereas SGR, PER and PWG values have been much higher to the ones observed in this experiment [15]. Protein Utilization (PER), growth rates (SGR) and weight gain (PWG) in this study, have generally been low and this has somehow been expected as individuals in this experiment have had an at least initial ten-fold weight compared to the initila weight of the juveniles used in the previously mentioned experiments.

It has been well substantiated that plasma cortisol levels are a reliable qualitative and quantitative index for stress condition in fish [16]. In this experiment, fish which have received dietary probiotics (either in natural or controlled temperature) had lower serum cortisol levels $(7.04-12.18 \mu \mathrm{g} / \mathrm{dl}$ ) than those which had not received dietary probiotics $(17.77-20.53 \mu \mathrm{g} / \mathrm{dl})$, indicating that probiotics have increased the stress resistance of fish throughout the experiment (Tables 9, 10). Cortisol levels in salmonids under stress usually range between 4-20 $\mu \mathrm{g} / \mathrm{dl}$ [17]. However, higher levels have been observed in salmonids exposed to multiple stress factors [18], [19]. The observed cortisol levels in this experiment fall within the range of levels observed in previous experimentation for salmonids.

The oxygen depletion test has created much higher cortisol levels at all groups (Table 11), compared to the ones at normoxic conditions (Tables 9, 10). Furthermore fish kept at lower temperature during the oxygen depletion test had lower serum cortisol levels $(20.07-22.73 \mu \mathrm{g} / \mathrm{dl})$ than those kept at higher temperature $(23.78-25.67 \mu \mathrm{g} / \mathrm{dl})$ indicating that the former were less stressed than the latter, confirming the psychrophilic nature of rainbow trout. In addition, the beneficial effect of probiotics has been more pronounced at the P19 group (cortisol $20.07 \mu \mathrm{g} / \mathrm{dl}$ ) compared to the P17 group (cortisol $22.73 \mu \mathrm{g} / \mathrm{dl})$.

Due to their hypertonic internal tissue environment, freshwater fish tend to loose $\mathrm{Na}^{+}$and $\mathrm{Cl}^{-}$ions which are reinstated by active transport mechanisms in the oxyntic gill cells. It has been well documented that these mechanisms are adversely affected by stress [20]. In this experiment, the administration of probiotics have positively affected the serum ionic levels, as fish which have received probiotics have kept their serum $\mathrm{Na}^{+}$and $\mathrm{Cl}^{-}$more stable and without pronounced fluctuations, even after the oxygen depletion test (Tables 9, 11). 
Although no pronounced effect on growth and protein utilization has been shown in this experiment and all experiments so far for rainbow trout by using dietary Pediococcus acidilactici, the mechanism of the alternative complement has been well subtantiated that has increased and remained higher for 8 weeks of the initial feeding, showing the beneficial stimulation that $P$. acidilactici had on this important innate defense mechanism in rainbow trout [14]. Furthermore, the administration of $P$. acidilactici in rainbow trout has been proven beneficial towards the prevention of the vertebral column compression syndrome [21] .

In conclusion, the administration of $P$. acidilactici in rainbow trout enhances its welfare and disease resistance and it is therefore suggested that $P$. acidilactici should be used in rainbow trout diets. However more experimentation should be followed by investigating its effects on various sizes, biological stages and culture systems for the species in order to optimize the use of such diets and render their use more cost-effective in the long-term.

\section{REFERENCES}

[1] Kampouris T., Chatzinikolaou A., Zambelis A., Batjakas I. (2018). Aquaculture: the offshore challenge in EU and Greece. Conference: ECHOPOLIS: Nature and culture-based strategies and solutions for cities and territories, 26-28 November 2018, Eugenides Foundation, Athens.

[2] Varadi L. (2010). Europe: Regional Review. Global Conference on Aquaculture. September 22-25, 2010, Phuket, Thailand, FAO.

[3] Irianto A. and Austin, B. (2002b). Probiotics in aquaculture. J. Fish Dis., 25, 633-642.

[4] Newaj-Fyzul A., Adesiyun A., Mutani, A., Ramsubhag A., Brunt J., Austin B. (2007). Bacillus subtilis AB1 controls Aeromonas infection in rainbow trout (Oncorhynchus mykiss, Walbaum). Journal of Applied Microbiology 103,1699-1706. doi:10.1111/j.1365-2672.2007.03402.x

[5] Nikoskelainen S., Ouwehand A., Salminen S., Bylund G. (2001). Protection of rainbow trout (Oncorhynchus mykiss) from furunculosis by Lactobacillus rhamnosus. Aquaculture, 198, 229-236.

[6] Panigrahi A., Kiron V., Puangkaew J., Kobayashi T., Satoh S. and Sugita H. (2005). The viability of probiotic bacteria as a factor influencing the immune response in rainbow trout Oncorhynchus mykiss. Aquaculture, 243 (1-4), 241 - 254.

[7] Robertson P.A.W., O’Dowd C., Burrells C., Williams P. and Austin B. (2000). Use of Carnobacterium sp. as probiotic for Atlantic salmon (Salmo salar L) and rainbow trout (Oncorhynchus mykiss, Walbaum). Aquaculture 185(3-4), 235-243.

[8] Irianto A and Austin, B (2002a). Use of probiotics to control furunculosis in rainbow trout, Oncorhynchus mykiss (Walbaum). J Fish Dis., 25, 333-342.

[9] Burbank D.R., Shah D.H., LaPatra S.E., Fornshell G., Cain K.D. (2011). Enhanced resistance to coldwater disease following feeding of probiotic bacterial strains to rainbow trout (Oncorhynchus mykiss). Aquaculture 321, 185-190.

[10] Sakai M., Yoshida T., Astuta S., Kobayashi M. (1995). Enhancement of resistance to vibriosis in rainbow trout, Oncorhynchus mykiss (Walbaum) by oral administration of Clostridium butyricum bacteria, J. Fish. Dis., $18,187-190$.

[11] Regulation(EC)911/2009 of 29 September 2009, Concerning the Authorisation of a New Use of the Preparation of Pediococcus acidilactici CNCM MA 18/5M as a Feed Additive for salmonids and shrimps (holder of authorisation Lallemand SAS). Off. J. European Union, 30/09/2009 L257/10-L/11.

[12] Henrique M.M.F., Gomes E.F., Gouillou-Coustans M.F., Oliva-Teles A., Davies S.J. (1998). Influence of supplementation of practical diets with vitamin $\mathrm{C}$ on growth and response to hypoxic stress of seabream, Sparus aurata. Aquaculture 161, 415-426.

[13] Gunther J., Jimenez-Montealegre R. (2004). Effect of the probiotic Bacillus subtilis on the growth and food utilization of tilapia (Oreochromis niloticus) and prawn (Macrobrachium rosenbergii) under laboratory conditions. Rev. Biol. Trop. 52, 937-943.

[14] Ramos M.A., Gonçalves J.F.M., Batista S., Costas B., Pires M.A., Rema P., Ozorio R.O.A. (2015). Growth, immune responses and intestinal morphology of rainbow trout (Oncorhynchus mykiss) supplemented with commercial probiotics. Fish \& Shellfish Immunology, 45,19-26.

[15] Merrifield D.L., Bradley G., Harper G.M., Baker R.T.M., Munn C.B., Davies S.J. (2011). Assessment of the effects of vegetative and lyophilized Pediococcus acidilactici on growth, feed utilization, intestinal colonization and health parameters of rainbow trout (Oncorhynchus mykiss Walbaum). Aquaculture Nutrition, 17(1), 73-79. 
[16] Patiño R, Redding JM, Schreck CB (1987). Interrenal secretion of corticosteroids and plasma cortisol and cortisone concentrations after acute stress and during seawater acclimation in juvenile coho salmon (Oncorhynchus kisutch). General and Comparative Endocrinology, 68, 431-439.

[17] Pickering AD, Pottinger TG (1989). Stress responses and disease resistance in salmonid fish: Effects of chronic elevation of plasma cortisol. Fish Physiology and Biochemistry, 7, 253-258.

[18] Barton BA, Schreck CB, Sigismondi LA (1986). Multiple acute disturbances evoke cumulative physiological stress responses in juvenile chinook salmon. Transactions of the American Fisheries Society, 115, 245-251.

[19] Maule AG, Schreck CB, Bradford CS, Barton BA (1988). Physiological effects of collecting and transporting emigrating juvenile chinook salmon past dams on the Columbia River. Transactions of the American Fisheries Society, 117, 245-261.

[20] Wendelaar Bonga SE (1997). The stress response in fish. Physiological Reviews, 77, 591-625.

[21] Aubin J., Gatesoupe F.-J., Labbe L. \& Lebrun L. (2005). Trial of probiotics to prevent the vertebral column compression syndrome in rainbow trout (Oncorhynchus mykiss Walbaum). Aquacult. Res., 36, 758-767.

Citation: Panagiotis A. Pantazis et.al., "The Effect of Dietary Probiotics on Growth, Survival and Stress Resistance of Rainbow Trout (Onchorynchus Mykiss Walbaum)". International Journal of Innovative Studies in Aquatic Biology and Fisheries, 5(2), pp.1-7. DOI: http://dx.doi.org/10.20431/2454-7670.0502001

Copyright: (C) 2019 Authors. This is an open-access article distributed under the terms of the Creative Commons Attribution License, which permits unrestricted use, distribution, and reproduction in any medium, provided the original author and source are credited. 